\title{
Rare case of bilateral incarcerated obturator hernia:
}

\section{a case report}

\author{
Engin Hatipoğlu, M.D., ${ }^{1}$ Fatih Dal, M.D., ${ }^{1}$ Veysel Umman, M.D., ${ }^{1}$ Süleyman Demiryas, M.D., ${ }^{1}$ \\ Oktay Demirkıran, M.D., ${ }^{2}$ Metin Ertem, M.D., ${ }^{1}$ Sabri Ergüney, M.D., ${ }^{1}$ Salih Pekmezci, M.D. ${ }^{1}$
}

${ }^{1}$ Department of General Surgery Istanbul University Cerrahpaşa Faculty of Medicine, İstanbul-Turkey

${ }^{2}$ Department of Anesthesiology and Reanimation, İstanbul University Cerrahpaşa Faculty of Medicine, İstanbul-Turkey

\begin{abstract}
Here, we report the case of an 84-year-old woman with acute mechanical intestinal obstruction (AMIO) who was admitted to our Emergency Department. Computed tomography (CT) scan revealed an incarcerated bilateral obturator hernia, and the defect was resolved using transabdominal preperitoneal (TAPP) technique with polypropylene mesh. The patient was administered an oral regimen two days after the operation. The patient stayed in the intensive care unit for 4 days and was uneventfully discharged on the 9th postoperative day. Follow-up was scheduled at the 6th month, during which no adverse events were detected and the patient did not report any complaints. Obturator hernia is among the differential diagnoses of intestinal obstruction requiring early diagnosis and prompt surgical intervention. Laparoscopic approach is less invasive compared with open surgery, and it can be attempted in cases presenting with no sign of ischemia or peritonitis. TAPP technique should be preferred since it allows the control of all intraabdominal pathologies and the viability of the intestines.
\end{abstract}

Keywords: Hernia; laparoscopy; obsutruction; obturator.

\section{INTRODUCTION}

Obturator hernia is rare among abdominal wall hernias, with an incidence of $0.05 \%$ to $1.4 \%{ }^{\left[{ }^{1]}\right.}$ Old age, high intraabdominal pressure, pelvic floor dysfunction, and multiparity have been found to be predisposing factors. ${ }^{[2]}$ Because this is a rare but serious condition with a high mortality rate, understanding its characteristics is important to suspect and easily diagnose $\mathrm{OH}$.

Here, we report the case of an 84-year-old woman with acute mechanical intestinal obstruction (AMIO) who was admitted to our Emergency Department. CT scan revealed an incarcerated bilateral obturator hernia, and she underwent laparoscopic repair via transabdominal preperitoneal (TAPP) approach.

\section{CASE REPORT}

An 84-year-old female patient presented to our Emergency Department with nausea, vomiting, and pain in the abdomen and right hip. She presented with a history of chronic renal failure and arterial hypertension. Physical examination revealed abdominal distension and diffuse abdominal tenderness.

Blood tests revealed leukocytosis $\left(23.000 / \mathrm{mm}^{3}\right)$ and high CRP (42.6 mg/dl), BUN (198 mg/dl), and creatinine $(8.92 \mathrm{mg} / \mathrm{dl})$ levels. Other values were normal.

Abdominal X-ray revealed dilated small bowel loops with gasfluid levels. Oral and rectal contrast-enhanced abdominal CT revealed a distal ileal loop herniated bilaterally to the obtu-

Cite this article as: Hatipoğlu E, Dal F, Umman V, Demiryas S, Demirkıran O, Ertem M, et al. Rare case of bilateral incarcerated obturator hernia: a case report. Ulus Travma Acil Cerrahi Derg 2018;24:278-280.

Address for correspondence: Engin Hatipoğlu, M.D.

İstanbul Üniversitesi Cerrahpaşa Tıp Fakültesi, Genel Cerrahi Anabilim Dalı, İstanbul, Turkey

Tel: +90 212 - 4142424 E-mail: enginhatipoglu@yahoo.com

Ulus Travma Acil Cerrahi Derg 2018;24(3):278-280 DOI: 10.5505/tjtes.2018.36559 Submitted: 02.12.2017 Accepted: 07.03.2018 Online: 08.05.2018

Copyright 2018 Turkish Association of Trauma and Emergency Surgery 
rator canal and proximal bowel loops dilated up to $3.5 \mathrm{~cm}$ in diameter (Fig. I). After a brief preparation, the patient underwent an emergency surgical operation with a diagnosis of bilateral incarcerated obturator hernia. Diagnostic laparoscopy revealed distal ileal loops bilaterally entrapped into the obturator canal (Fig. I). No sign of bowel ischemia or perforation was observed. The defect was repaired using TAPP technique with polypropylene mesh (Fig. I). The patient was administered an oral regimen two days post-operation.

The patient stayed in the intensive care unit for 4 days and was uneventfully discharged on the 9th postoperative day. Follow-up was scheduled at the 6th month, in which no adverse events were noted and the patient did not report any complaints.

\section{DISCUSSION}

Obturator hernia is a rare but serious condition, and its diagnosis considered in cases with an intestinal obstruction. The most common presenting sign is intestinal obstruction, followed by abdominal pain. ${ }^{[3]}$ Delay in diagnosis can result in morbidity and mortality. ${ }^{[1]}$

Abdominal X-ray and ultrasound can provide useful information, but early CT scan is crucial and has been shown to decrease morbidity and mortality. CT is an indispensable modality in preoperatively determining any signs of ischemia or infarct, and thus, has a major effect when selecting the appropriate operative approach.

Although most of the obturator hernia cases in the literature are unilateral, reported cases of bilateral hernia are available as well. Tee et al. ${ }^{[4]}$ have reported a case that presented with intestinal obstruction and was discharged with no complaints after conservative treatment. The patient was readmitted I month later with the same complaints and was operated with a diagnosis of bilateral obturator hernia. In cases of obturator hernia, a conservative approach is not recommended.

When patients present with obstruction and signs of ischemia, obturator hernia is generally repaired with open sur- gical technique. Although abdominal, inguinal, preperitoneal, and laparoscopic approaches have been defined, minimally invasive laparoscopic approach is preferred today.

In a review of 28 cases that were laparoscopically operated, 8 were treated TAPP mesh repair, 15 with totally extraperitoneal (TEP) mesh repair, 4 with direct repairs by stapling or suturing, and I with intraperitoneal plug repair. While 6 patients of the 8 in the TAPP group were operated for emergency presentations, all TEP repairs were electively performed. ${ }^{[5]}$

In a recent study by Karashima et al., ${ }^{[6]}$ of the 22 patients examined, 10 underwent laparotomy and 12 underwent laparoscopic operation with TEP technique. In 3 patients, the operation was converted to open surgery. The duration of operation and blood loss were comparable in both techniques, and the length of hospital stay was shorter in the laparoscopic group.

Hayama et al. ${ }^{[7]}$ have recently reported six cases of obturator hernia treated with TAPP approach. In two of these patients, bowel resection was performed. Synthetic mesh was used in five patients, and one case was repaired with simple peritoneal closure. In cases with ischemia/necrosis, open surgery can be preferred for the resection and anastomosis of the necrotic segments. Thus, except for cases with bowel necrosis and peritonitis, laparoscopy is a suitable technique because it is minimally invasive and enables both the diagnosis and treatment of obturator hernia.

\section{Conclusions}

Obturator hernia is among the differential diagnoses of intestinal obstruction requiring early diagnosis and prompt surgical intervention. Laparoscopic approach is less invasive compared with open surgery, and it can be attempted in cases presenting with no sign of ischemia or peritonitis. TAPP technique should be preferred since it allows the control of all intraabdominal pathologies and the viability of the intestines.

\section{Conflict of interest: None declared.}
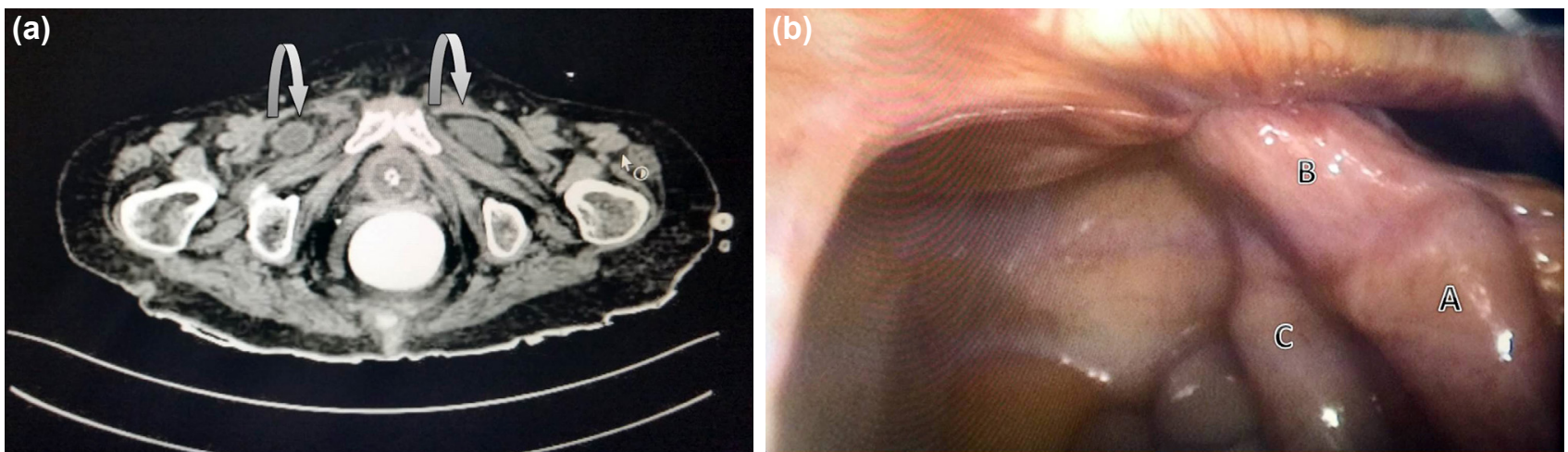

Figure 1. (a, b) A Afferent loop, B incarcerated segment, and C efferent loop. 


\section{REFERENCES}

1. Mandarry MT, Zeng SB, Wei ZQ, Zhang C, Wang ZW. Obturator hernia-a condition seldom thought of and hence seldom sought. Int J Colorectal Dis 2012;27:133-41. [CrossRef]

2. Ng DC, Tung KL, Tang CN, Li MK. Fifteen-year experience in managing obturator hernia: from open to laparoscopicapproach. Hernia 2014;18:381-6. [CrossRef]

3. Shukla S, Garge S. Obturator hernia of the Richter type: A case report. Indian J Surg 2010;72:299-301. [CrossRef]

4. Tee CL, Evans T, Ratnayake S, Strekozov B. Small bowel obstruction secondary to bilateral obturator hernia: a rare occurrence. J Surg Case Rep. 2014;2014. pii: rju009.

5. Deeba S, Purkayastha S, Darzi A, Zacharakis E. Obturator hernias: A review of the laparoscopic approach.J Minim Access Surg 2011;7:201-4.

6. Karashima R, Kimura M, Taura N, Shimokawa Y, Nishimura T, Baba H. Total extraperitoneal approach for incarcerated obturator hernia repair. Hernia 2016;20:479-82. [CrossRef]

7. Hayama S, Ohtaka K, Takahashi Y, Ichimura T, Senmaru N, Hirano S. Laparoscopic reduction and repair for incarcerated obturator hernia: comparison with open surgery. Hernia 2015;19:809-14. [CrossRef]

\section{OLGU SUNUMU - ÖZET}

\section{Nadir görülen inkarsere iki taraflı obturator herni: Olgu sunumu \\ Dr. Engin Hatipoğlu, ${ }^{1}$ Dr. Fatih Dal, ${ }^{1}$ Dr. Veysel Umman, ${ }^{1}$ Dr. Süleyman Demiryas, ${ }^{1}$ Dr. Oktay Demirkıran, ${ }^{2}$ Dr. Metin Ertem, ${ }^{1}$ Dr. Sabri Ergüney, ${ }^{1}$ Dr. Salih Pekmezci ${ }^{1}$}

${ }^{1}$ İstanbul Üniversitesi Cerrahpaşa Tıp Fakültesi, Genel Cerrahi Anabilim Dalı, İstanbul

${ }^{2}$ İstanbul Üniversitesi Cerrahpaşa Tıp Fakültesi, Anesteziyoloji ve Reanimasyon Anabilim Dalı, İstanbul

Acil cerrahi kliniğimize akut mekanik intestinal obstrüksiyon semptomları ile başvuran 84 yaşında kadın hasta sunuldu. Bilgisayarlı tomografi görüntülemesinde iki taraflı inkarsere obturator herni saptandı. Defektler poliprolen yama kullanılarak Trans Abdominal Pre Peritoneal (TAPP) tekniği uygulanarak tamir edildi. Hasta ameliyat sonrası dört gün boyunca yoğun bakım ünitesinde takip edildi, dokuzuncu gün sorunsuz taburcu edildi. Altıncı ay kontrollerinde herhangi bir sorunla karşılaşılmadı. Obturator herni, intestinal obstrüksiyonun ayıııı tanısında düşünülmesi gereken, erken tanı ve uygun cerrahi tedavi gerektiren bir kliniktir. Laparoskopik yaklaşım, açık yaklaşıma göre daha az invaziv olup, iskemi ve peritonit bulgusu olmayan olgularda denenebilir. Bu hastalarda TAPP tekniği, tüm intraabdominal patololerin değerlendirilmesi ve bağırsakların görüntülenebilmesi nedeniyle tercih edilmelidir.

Anahtar sözcükler: Herni; laparoskopi; obstrüksiyon; obturator.

Ulus Travma Acil Cerrahi Derg 2018;24(3):278-280 doi: 10.5505/tjtes.2018.36559 